\title{
Higher education in the IPSAS implementation process: A comparative study
}

\section{between Brazil and Mexico}

\author{
Processo de implantação das IPSAS no ensino superior: Um estudo comparado entre Brasil e \\ México
}

Proceso de implementación de las IPSAS en la educación superior: Un estudio comparativo entre Brasil y México

Fernando Gentil de Souza

ORCID: https://orcid.org/0000-0003-3504-7872 Universidade Federal de Pernambuco, Brazil

E-mail: Fernando.gentil@ufpe.br

Débora de Oliveira Barros

ORCID: https://orcid.org/0000-0002-2129-6758

Universidade Federal de Pernambuco, Brazil

E-mail:ebora_o.b@hotmail.com

Laura Margarita Medina Celis ORCID https://orcid.org/0000-0002-3696-7243 Universidad de Guadalajara, Mexico E-mail: medinacelis@gmail.com

Jamille Carla Oliveira Araújo

ORCID https://orcid.org/0000-0002-2273-2347

Universidade Federal de Pernambuco, Brazil E-mail: jamille.carla@ufpe.br

\begin{abstract}
The Brazil and Mexico started their International Public Sector Accounting Standards (IPSAS) IPSAS adoption strategies in 2008 and consider the importance of the accountant role in this process and the existence of specific undergraduate Accounting programmes in the two countries. This study aims to compare the offer of courses about public sector accounting in public institutions of higher education in these countries during year 2018 \& 2019, under Institutional Theory perspective. The methodology of this article consists of a documentary analysis of the curricula in force of website of the Public Institutions of Higher Education (PIHE) of each federative entity of Brazil and Mexico. The results show great diversity in the offer of disciplines among the 76 Brazilian and in the 39 Mexican institutions, with an average of only 3 and 1,3 courses by each country respectively. In Brazil, every institution has at least one mandatory Public Sector Accounting discipline, whilst only 28 Mexican institutions offer as obligatory. If institutional legitimacy consider education in Mexican and Brazilian IPSAS adoption strategies, the diffusion of IPSAS accrual accounting information will account for a huge network of more than 1000 of people involved. Furthermore, it highlights the weakness of the public sector approach to develop professional skills (normative isomorphism) in line with emerging trends in Public Sector Accounting for transparency. This article contributes to show what has been considered from the perspective of higher education of future public sector accounting professionals aligned with the IPSAS adoption strategies that involve Brazil and Mexico.
\end{abstract}

Keywords: Public sector accounting; IPSAS; International convergence; Higher education; Comparative analysis.

\section{Resumo}

O Brasil e o México iniciaram suas estratégias de adoção das Normas Internacionais de Contabilidade do Setor Público (IPSAS) e consideram a importância da atuação do contador neste processo e a existência de programas específicos de graduação em Contabilidade nos dois países. Nesse caminho o estudo tem como objetivo comparar a oferta de cursos sobre contabilidade do setor público em instituições públicas de ensino superior desses países durante os anos de 2018 e 2019, sob a perspectiva da Teoria Institucional. A metodologia adotada consiste em uma análise documental dos currículos vigentes nas Instituições Públicas de Ensino Superior (PIHE) do Brasil e do México. Os resultados mostram grande diversidade na oferta de disciplinas entre as 76 instituições brasileiras e as 39 mexicanas, com média de apenas 3 e 1,3 cursos por cada país respectivamente. No Brasil, cada instituição tem pelo menos uma disciplina obrigatória de Contabilidade do Setor Público, enquanto apenas 28 instituições mexicanas oferecem como obrigatória. Se a legitimidade institucional considerar a educação nas estratégias de adoção das IPSAS no México e no Brasil, a difusão das informações de contabilidade de exercício das IPSAS representará uma enorme rede de mais de 1000 pessoas envolvidas. Além disso, destaca a fraqueza da abordagem do setor público para desenvolver 
habilidades profissionais (isomorfismo normativo) da contabilidade do setor público para a transparência. Este artigo contribui para mostrar uma análise da formação superior dos futuros profissionais da contabilidade do setor público alinhado às estratégias de adoção das IPSAS que envolvem o Brasil e o México.

Palavras-chave: Contabilidade do setor público; IPSAS; Convergência internacional; Ensino superior; Análise comparativa.

\section{Resumen}

Brasil y México iniciaron sus estrategias para adoptar las Normas Internacionales de Contabilidad del Sector Público (IPSAS) y considerar la importancia del rol del contador en este proceso y en los programas específicos de contabilidad de pregrado en ambos países. De esta manera, el estudio tiene como objetivo comparar la oferta de cursos sobre contabilidad del sector público en instituciones públicas de educación superior en estos países durante los años 2018 y 2019, desde la perspectiva de la Teoría Institucional. La metodología consiste en un análisis documental de los planes de estudio vigentes en las Instituciones Públicas de Educación Superior (PIHE) en Brasil y México. Los resultados muestran una gran diversidad en la oferta de disciplinas entre 76 instituciones brasileñas y 39 mexicanas, con un promedio de solo 3 y 1.3 cursos para cada país, respectivamente. En Brasil, cada institución tiene al menos un curso obligatorio de Contabilidad del Sector Público, mientras que solo 28 instituciones mexicanas lo ofrecen como obligatorio. Dada la legitimidad institucional para considerar la educación en las estrategias de adopción de las IPSAS en México y Brasil, la difusión de la información contable del ejercicio de las IPSAS llegará a una enorme red de más de 1000 personas involucradas. Además, destaca la debilidad del enfoque del sector público para el desarrollo de habilidades profesionales (isomorfismo normativo) de la contabilidad del sector público para la transparencia. Este artículo contribuye a mostrar un análisis de la educación superior de los futuros profesionales de la contabilidad del sector público en adopción de IPSAS.

Palabras clave: Contabilidad del sector público; IPSAS; Convergencia internacional; Educación superior; Análisis comparativo.

\section{Introduction}

Many countries are adhering to the International Public Sector Accounting Standards (IPSAS). This study aims to analyze the supply of courses about the Public Sector in public institutions of higher education (PIHE) in Brazil and Mexico. In this way, the IPSAS adoption in these countries can be observed from the perspective of professional preparation.

The modernization of accounting, made possible by the adoption of IPSAS, depends on the ability of accounting professionals to provide improved accountability and transparency, that is, information on the management of public resources. It is expected with the IPSAS adoption the minimization of corruption and fraud, so that accounting can contribute to accountability (Jorge de Jesús \& Eirado, 2012) and aid in meeting social needs.

This paper analyze the curriculum of the Accounting undergraduate courses of public institutions of higher education in Brazil and Mexico in 2019. This empirical documentary study is based on the information available on the webpages of each institution. The comparative analysis is justified by the answer to the adoption of IPSAS in the two countries and also due to their economic importance.

Brazil participates in the Southern Common Market (MERCOSUL), the first full customs union and trading block in the continent of South America. It was founded in 1991 by the Treaty of Asunción in Paraguay, under the impetus of the then presidents Fernando Collor de Melo of Brazil and Carlos Menem of Argentina. The objective was to create a common market between four countries: Brazil, Argentina, Uruguay and Paraguay. Brazil was also included in 2001 in the group called BRICS (Brazil, Russia, India, China and South Africa). The term was coined by the Goldman-Sachs group and refers to countries outside the developed and western axis, with the main objective of influencing global geopolitics and the market as an alternative to the Europe-US hegemony (Gómez-Villegas, Brusca, \& Bergmann2020, Lobato, 2018).

Mexico, since May 1994, is the $25^{\text {th }}$ member of the Organization for Economic Cooperation and Development (OECD). Mexico retains experience from other countries with best international practices to strengthen their public and political administration. Their entry into the group led to the opening of the OECD to the world and to its economic development, with the intention of boosting the market economy, living standards of the population, the democratic system, the expansion of trade and the exchange of information (Flores, 1994). 
Mexico has a network of 12 free trade agreements involving 46 countries (SNCI, 2017). Among them there are agreements with North America since 1994, with the European Union since 2000, and with Central and South Americas since 1995. Such agreements aim to develop trade in goods, services, investment, technology transfer, intellectual property, double taxation, economic cooperation, among others. Another example is the Pacific Alliance which, to date, is still in negotiation. With MERCOSUL, it has signed two economic complementation agreements since 2002.

Brazil and Mexico also coincide with the year of the beginning of the convergence with IPSAS, since both started in 2008. In Brazil, the convergence process started with the Ordinance 184 issued by the Ministry of Finance and Decree 6.976/2009, which guides the process. In Mexico, the government issued the General Law of Government Accounting in the Official Gazette of the Federation on December 31, 2008. In this law, it is the National Council of Accounting Harmonization, wich issues provisions since 2009 to coordinate the process.

Therefore, this study seeks to reveal how the Universities of these two Latin American countries are preparing their professionals to advance in the harmonization, since IPSAS is a New Public Management accounting tool. The methodology is based on bibliographic and data analysis, which assists in the understanding of the problem studied and enables the descriptive analysis of the current situation of the countries, made through researches in the Universities of the 27 Brazilian federal units and 32 Mexican.

In the next section, it present the backgroung of the undergraduate accounting programmes for both Brazil and Mexico, highlighting the legislation surrounding higher education and the government organizations that play an important role on defining them. Afterwards, it revise the present literature, specifically when it comes to Institutional Theory, which is going to be essential to understand and analyze the results. This leads to a section on the research methods. Section five, then, presents our findings, by describing the courses and its characteristics of the universities participating in the sample. Finally, it analyze the situation of the courses regarding government accounting, interpreting and comparing the information of both countries, and present our conclusions, along with some suggestions for further research.

\section{Literature Review}

\subsection{Accounting Programmes in Brazil}

Currently, there are more than 30,000 courses in higher education institutions in Brazil (Dias et. al. 2021). Of these, approximately $30 \%$ correspond to the area of Social Sciences, Administration and Business, which is the area where more courses are offered in the whole country. The information provided by the Ministry of Education and Culture (MEC) makes it possible to identify the situation of the higher education, including the number of public and private institutions in each region. In this case, $12.6 \%$ of the Institutions of Education are public and $87.4 \%$ are private. According to MEC, the number of courses offered is directly related to the population of each region.

In order to measure the provision of training, the curricula of the undergraduate Accounting programmes of the public institutions of higher education were analysed, particularly the disciplines related to the public sector, as a response to the needs of the public sphere.

In Brazil, the rules for the provision of courses in relation to Accounting education are stipulated in the provisions of the Law on Guidelines and Bases of the Ministry of Education (Guedes, Castro \& Canedo, 2020). They are also included in Article 5 of the National Education Council, which discusses the organization of educational programs and projects of the public institutions of higher education. The latter states that programs can be developed independently but must consider essential requirements in vocational training. These include: "II - Vocational training content: specific studies on Accounting Theories, including actuarial activities and financial information, patrimonial, governmental and non-governmental, audits, forensics, arbitration, and control applied to the Public and Private Sector." 
With regard to professional training, the adoption of IPSAS in Brazil includes the strategies described in Ordinances 828 of 2011 and 231 of 2012, with a timetable for the implementation of the main aspects:

i. recording of tax credits, according to the accrual basis of accounting

ii. recording of obligations and provisions on an accrual basis

iii. recording of actual and intangible assets

iv. depreciation, amortization

v. infrastructure assets

vi. implementation of the cost system

vii. application of the chart of accounts

viii. Aspects of property foreseen in MCASP

Similarly, the professional training in IPSAS is based on discussions of Technical Groups of Accounting Procedures (GTCON) and reports of the Technical Group of Standardization of Reports (GTREL). These institutions, together with the Regional Councils of Accounting, Courts of Accounts and others, are the multipliers of the international standard. In addition, the Manual of Accounting Applied to the Public Sector is also published and distributed in the printed and digital versions.

It is important to highlight the need for changes to increase control in the public sector in Brazil and Mexico and, thus, avoid corruption. Higher education occupies a prominent place in the debates on developing transparency in public accounts. The changes in the profile of the accounting professional should consider the important existing standards in public administration, incorporating the knowledge of IPSAS procedures.

With regard to the Brazilian regulations for the implementation of IPSAS, the Federal Accounting Council (CFC) published the Brazilian Accounting Standards applied to the Public Sector (NBCASP) in 2008. Similarly, the National Treasury Secretariat (STN) published the Accounting Manual Applied to the Public Sector (MCASP) in 2009, with a new Accounts Plan and CASP procedures based on accumulation, as well as several directives that guide its implementation. Although the deadline for mandatory adoption at the local level has been postponed, some procedures should have already been adopted between 2016 and 2025 (Ordinance 548 of the STN). In line with the studies of Ademola et. al. (2020), Abdulkarim, Umlai, \& Al-Saudi, (2020), Pina, Torres and Yetano (2009), Souza (2016) found, in his study about the adoption of IPSAS in Brazilian local governments, a precarity of mandatory and voluntary information reported by the governments analyzed.

The curriculum is a guiding tool of the teaching process at any level, including higher education. International organizations such as the Intergovernmental Working Group of Experts on International Standards of Accounting and Reporting (ISAR), linked to the United Nations Conference on Trade and Development (UNCTAD), and the United Nations have developed a Model Accounting Curriculum, with the objective of stimulating the world's educational institutions. The disciplines of studies within the governmental area indicated by the Model Accounting Curriculum are: Public Audit, Public Accounting and Public Management (Caruana, 2021, Araújo et. al., 2018, Cavalcanti, 2013).

In Brazil, the CFC published in 2009 the so-called "National Content Proposal for the Graduate Course in Accounting Sciences", which defines the professional profile of the student in terms of skills and abilities. This document defines the curricular components, the evaluation systems of students and courses, the supervised curricular practices, the complementary activities, the project to completing the course (project or scientific article that the students must present), the scientific initiation project or project of activity as an optional component of the institution and the academic offer regime (CFC, 2009). In the end, this document shows the concern of the accounting body with professional training.

Although the CFC guidelines condition study plans indicating skills and abilities, it should be highlighted that the curriculum must be dynamic, flexible, and realistic. Making the curriculum more flexible means ensuring quality training 
(Gesser \& Ranghetti, 2011), which is necessary to meet the demands of society in the process of critical training of professionals.

Regarding the importance of the pertinent approach to CASP in the curricula, the Resolution of the National Council of Education states that the undergraduate course in Accounting should generate conditions for the future accountant to be qualified to: I - understand scientific, technical, social, economic and financial issues, nationally and internationally and in different organizational models; II - present full control of functional responsibilities, including calculations, audits, expert reports, arbitrations; notions of actuarial activities and quantification of financial, patrimonial and governmental information, with the full use of technological innovations.

The Resolution of the National Council of Education and of Higher Education (CNE/CES), of December 10, 2004, guides the Accounting programmes in Brazil. The courses that are part of the requirements specified by the CNE/CES should be included in the curriculum, as well as the appropriate workload for the learning to be carried out properly. One of the contemplated and specific areas in the regulations is inserted in the group of "notions of governmental information".

Understanding current social and cultural issues requires a new kind of education that addresses the multiple dimensions of man and society (Althoff \& Domingues, 2008). This need also concerns how the CASP study, in the specific accounting courses, benefits society and is used as a management tool in the public sector. In this context, CASP courses are important for the fulfillment of social demands, and more specifically for the improvement of the management and transparency of public administrations, as well as the teaching and implementation of IPSAS. At the same time, the number of disciplines and their workloads must be observed.

Gesser and Ranghetti (2011) point out that, considering the current challenges, it is up to the professional formation to prepare the students to act in front of the changes that occur. Thus, it emphasize the urgency in updating the curriculum of the Accounting programmes, highlighting the CASP courses, since education is the key to achieving the objectives. In this manner, it is worth highlighting the importance of curricula that give sufficient weight to the public sector, having to correspond to the expected improvements in the performance of the managers, and an adequate conformation that leads to the transparency and modernization of public management.

\subsection{Accounting Programmes in Mexico}

In Mexico, the National Accounting Harmonization Council (CONAC) has been giving basic guidelines with its standards, manuals, catalogs, reporting on moments of recognition of revenues and expenses, financial statements and information to disclose the public accounts. Mexican universities, which are linked to social progress, must allow government to achieve standards that are justified by the state and society (Ibarra, 2002).

Del Castillo's study (2005) noted that external evaluation has a positive impact on higher education institutions. There is the updating of the curricula that undergo an external diagnostic or accreditation evaluation, as well as improvements in the management of educational quality. As a result of this evaluation, the financing and quality policy encourages changes, such as: (1) in the allocation of public resources, through quasi-market mechanisms that allow the public institutions of higher education to compete for additional income in exchange for the adoption of evaluation rules; and (2) in the national evaluation strategy, through accreditation mechanisms that allow universities to consolidate and increase their prestige through the public recognition of the educational quality of their study plans.

The set of practices used in universities, colleges and schools can be identified through curriculum and syllabus. Their functions are to define what is intended as the ultimate goal, along with the other instruments of the learning process, such as pedagogical proposals. This section presents the importance of teaching CASP and its content to facilitate the process of adopting IPSAS. 
It is also necessary to regulate the supply of the rising educational modalities, such as long-distance education, as well as to consider the supply of foreign institutions and prescribe higher education in order to meet demands. These are: rules of accountability, auditing, public access to information, and public funding policies. In addition, the experience and knowledge of the Mexican Association of Control and Surveillance in Institutions of Higher Education that groups auditors and comptrollers of the Public Institutions of Higher Education should also be considered.

The structure that regulates higher education in public institutions is found in articles: (a) 3, fractions VII and VIII; (b) 5, 73, fraction XXV; (c) 121, fraction V; (d) 122c, first base, fraction V, subsection I; and (e) in 123 constitutionals laws, derived from them. The General Law on Education (2016), the Regulatory Law of article 5 of the Constitutional Law on the Exercise of Professions (1945), the Higher Education Coordination Law (1978), and the Law on Science and Technology (2002) are also regulaion sources. Added to these are the Organic Law of the Federal Public Administration, which refers to Secretaries of State that have competence in educational matters, the education laws of the states, and the laws or decrees of each institution.

The Government Accounting System (SCG) is based on Title Three, Chapter II, Section III, Article 73, Section XXVIII, of the Political Constitution of the United Mexican States, establishes, among other powers of Congress, that of "issuing laws on government accounting that will govern public accounting and the homogeneous presentation of financial information, income and expenses, as well as equity in order to ensure their harmonization at the national level." (SE, s.f.)

From the attribution of the Congress of the Union, the latter approved the Accounting Law that governs the three orders of government in the matter and creates the National Accounting Amortization Council (CONAC), as the coordinating body for the harmonization of the government accounting and empowers it to issue accounting standards and guidelines for the generation of financial information from public entities.

In Article 1 of the Accounting Law, it is established that: "It is mandatory for the Executive, Legislative and Judicial branches of the Federation, the states and the Federal District; the municipalities of the municipalities; the politicaladministrative organs of the demarcations of the current Mexico City, the entities of the parastatal public administration, whether federal, state or municipal and federal and state autonomous bodies." (SE, s.f.)

And in Article 33 of the Accounting Law, it is provided that government accounting should consider the best national and international accounting practices in support of the tasks of financial planning, resource control, analysis and control.

The SCG is made up of the set of records, procedures, criteria and structured reports based on common technical principles aimed at capturing, valuing, recording, classifying, reporting and interpreting transactions in a systematic way; transformations and identifiable and quantifiable events that, derived from economic activity and expressed in monetary terms, modify the economic, financial and patrimonial situation of public entities in particular and of public finances in general.

The SCG' public entities, must record in a harmonious, delimited and specific manner the budgetary and accounting operations derived from public management, as well as the Economic Flows. Similarly, you must periodically generate useful, reliable, relevant, timely, understandable and comparable financial statements, expressed in monetary terms. Within said framework, article 34 of the Accounting Law establishes that "the accounting records of public entities shall be kept on a cumulative basis". (SE, s.f.)

\subsection{Institutional Theory}

Several theories have helped to explain the adoption of reforms in government management, including the publicchoice, agency and institutional theories. The communication theory also recognizes the important role of accounting in the public sector. 
According to the Institutional Theory (IT), organizations have become more homogeneous and bureaucracy is a common feature in them. DiMaggio and Powell (1983) explain why in organizations it found homogeneity in forms but not in practices. They define how this homogeneity has been established.

The studies based on New Institutional Sociology (NIS) framework as a means for organizations to legitimize themselves and their actions by making them improve their performance while making strategies choices based in innovative goals (Yamoto \& Noguchi, 2013).

Social influences lead to organizations to accept and adopt appropriate practices explained by IT (DiMaggio and Powell, 1983).The same author presented a framework of NIS and explained isomorphism according to three distinguished mechanisms. Each with its own characteristics.

The first mechanism, coercive isomorphism, comes from political influence and the problem of legitimacy. The second, mimetic isomorphism, results from responses to uncertain standards. Organizations have a tendency to follow other organizations in their field, in order to be legitimate or successful. The latter, normative isomorphism is associated with professionalism and stakeholders pressures. Normative forces and innovations represented by professions and their associations are especially important (Oulasvirta, 2014)

Scapens (1994) offers a theoretical framework that allows to understand the institutional theory as an extension of the neoclassical theory. Accounting advances and their recognition by users strengthen the institutional importance of new mechanisms that alters routine accounting. The model developed by Burns and Scapens (2000) defines management accounting as a set of information systems that support objective oriented decisions. The authors explain that institutional theory shows that there is a relationship between the routine actions and institutions.

According to organizational changes, homogenization by coercive pressures results as a direct response to government instructions (DiMaggio \& Powell,1983). In the same line as Japanese local governments (Yamamoto \& Noguchi, 2013), Brazilian local governments depend on the financial support of the national government, as local allocation taxes.

Several factors encourage reforms in public accounting, which focus primarily on the adoption of accrual accounting. According to IPSAS, the accrual is an accounting basis in which transactions and other events are recognized when they "occur" and differ from cash basis - thus, it is based on performing accounting and recognize only at the time of collection or payment. To implement a new accrual base accounting, the capacity to overcome technical and conceptual difficulties is essential (Soguel, \& Luta, 2021, Mnif, \& Gafsi, 2020, Lande \& Rocher, 2011).

\section{Methodology}

For the development of this study, a descriptive, qualitative research was chosen to bring more proximity to the object of study and thus making it possible to make relevant reflections on the comparisons of public sector accounting disciplines, in accounting science courses, in public institutions of higher education in these countries during the years 2018 and 2019, from the perspective of Institutional Theory, making it possible to understand the information obtained (Gil, 2002; Lakatos \& Marconi, 1991).

This research analyzes the curriculum presented in the website of the public institutions of higher education that offer an Accounting programme of each federative unit of Brazil and Mexico. It was selected the universities that had information available on the website about the undergraduation and its curriculum of the Accounting programme. In some cases, the curriculum was not available, but the universities presented the programme's syllabus, which was also used as data source. In just one case the university, namely Universidad Autónoma de Guerrero, did not present the curriculum neither the subjet programme's, causing its exclusion from the sample. This gave us a sample of 76 Brazilian universities and 38 Mexican universities. 
To obtain the data, we followed the steps according to: 1.Acces to the institutions websites, 2.Analyzis of the Accounting programmes curriculum. 3.Gathering of information related to governmental accounting courses and 4.Content analyzis through comparative tables.

It was accessed the websites of the institutions through the website of the Brazilian Ministry of Education (MEC) and the Mexican Secretary of Higher Education (SES) of the Secretary of Public Education. Afterwards, was analyzed the curriculum of the undergraduate Accounting programmes and gathered information related to courses that teach governmental accounting.

The analysis of the websites undergraduate in the universitys accounting programme was carried out during years of 2018 and 2019. Through the collected data, it is highlight which are the obligatory and elective courses within each curriculum, the course workload, the semester in which they are offered, the number of courses, and their names.

Having the institutions' websites listed on the websites of MEC and SES made this process much easier. In most cases, universities have their own pages that present their curriculum and subject program.

The licenciatura modality in Mexico compares to what in Brazil is called baccalaureate, since the programme workload and the degree of theoretical thoroughness of these modalities are equivalent. Therefore, our sample was based on undergraduate programmes in Mexico and Brazil, so that it had a good comparability.

In Mexico, the location of the programmes' curriculum is standardized. On the institutions' main website is the "Educational Offer". This part shows the programmes offered and their information, or leads to the website of the college that offers them, where the needed information can be found.

In both countries government and corporate accounting are taught in the same programme. In Brazil, it is called Contabilidade, which is divided between societária and pública; but in México, the Accounting is called Contaduría Pública, which is divided between empresarial and gubernamental.

After data collection, it was performed a content analysis using comparative tables contrasting the two countries, observing its similarities, differences and notable points (cf. Table 1 - Summary of the main results).

\section{Results}

First, it is show a summary of the main results obtained in the table 1, which are explained below and detailed in the Appendix I and II.

It was analyzed 25 of the 27 federative units in Brazil, since two universities did not have the required information available. There are 76 Brazilian Public Institutions of Higher Education, with the government accounting courses varying between 82 different denotations for the 225 courses analyzed. It is possible to notice that the Brazilian Accounting programme curriculum has at least one mandatory government accounting course, with an average of 3 courses per institution and a total workload of 125 hours (an average of 62 hours per course).

Meanwhile, it was analyzed 31 of the 32 Mexican Federative entities, since one of them (Guerrero) does not offer the Accounting programme in the public institution of higher education. Hence, we analyzed 39 Mexican public institutions. In the Mexican curricula, it is possible to notice 15 different denotations for the 39 government accounting courses, with only 29 public institutions offering at least one mandatory course in the subject. In the Mexican case, there is an average of 1.3 government accounting courses per institution - thus, we highlight that Brazil stands out for offering more courses related to the public sector. The total workload average of the government accounting courses is 101 hours, with an average of 60 hours of workload per couse, which means that both countries are very similar in this particular aspect - despite some Mexican institutions lacking a government accounting course. 
Table 1 - Summary of the main results.

\begin{tabular}{lcc}
\hline & Brazil & Mexico \\
\hline Analyzed states & 25 & 31 \\
Amount of PIHE analyzed & 76 & 39 \\
Denotations & 82 & 15 \\
Courses & 225 & 38 \\
Workload per course average & $62 \mathrm{~h}$ & $60 \mathrm{~h}$ \\
Courses per institution average & 3 & 2 \\
Total workload average & $125 \mathrm{~h}$ & $101 \mathrm{~h}$ \\
Highlighted PIHE & UnB, UFRN, UERN $^{1}$ & UASLP, $_{\text {UAT }}^{2}$ \\
Amount of PIHE with at least one & 76 & 29 \\
mandatory course & & \\
\hline
\end{tabular}

Source: Research data.

\subsection{Denotations for courses related to the government sector}

Both countries offer courses with similar denotations (cf. Table 2 - Most common courses in both countries for the most frequent denotations of courses related to government accounting). In Mexico, there are denotations such as Forensic and Governmental Audit, Governmental Fiscal Audit, Local Tax Management: Expenditures with Related Income, Accounting Record and its Validation in Governmental Organs, and Transparency and Accountability. On the other hand, In Brazil, there are courses such as Advanced Topics in Government Accounting, New Forms of Organization in the Public and Private Scope, Planning, Participatory Budgeting and Municipal Management, Political Science and General Theory of the State.

Table 2 - Most common encountered courses.

\begin{tabular}{l}
\hline Accounting Applied to the Public Sector \\
\hline Public Accounting \\
\hline Accounting for Public Institutions \\
\hline Government Accounting and Audit \\
\hline Public Accounting and Budgeting \\
\hline Public Financial Administration \\
\hline Public Administrations \\
\hline Public Budgeting and Planning \\
\hline Public Budgeting \\
\hline Public Budgeting and Management \\
\hline Public Auditing \\
\hline Government Auditing \\
\hline Government Auditing and Controlling \\
\hline Control e Evaluation of Public Management \\
\hline Public Finances \\
\hline Public Finances and Budgeting \\
\hline Public Institutions Planning and Budgeting \\
\hline Public Management Execution \\
\hline Governament Practice
\end{tabular}

Source: Research data.

${ }^{1}$ UnB: Universidade de Brasília; UFRN: Universidade Federal do Rio Grande do Norte; UERN: Universidade Estadual do Rio Grande do Norte

${ }^{2}$ UASLP: Universidad de San Luis Potosí; UNAM, Universidad Nacional Autónoma de México; UAT: Autónoma de Tamaulipas 
The variety of courses' denotations used in both countries shows the lack of definition and standardization, suggesting the need for a national model. It is appropriate to organize and clarify the contents and courses to be taught in the curriculum so that future professionals follow the changes arising from the adoption of IPSAS and achieve the necessary skills.

The accounting structure of direct and indirect public administration of cities have similar formats, including in the chart of accounts. This reflects on the need to vary the courses offered in public institutions of higher education. It was noticed 82 different definitions in the 228 disciplines analyzed in Brazil and 17 different definitions for the 34 in Mexico. The most frequent names are "Government Accounting" and "Government Audit". In the case of Brazil, the Accounting Manual published by the National Treasury Secretariat guides the accounting curriculum indicating the term "Accounting Applied to the Public Sector", which is only used in 7 institutions. The most commonly used definition is "Public Accounting."

According to Ramírez-Alujas (2011), the importance of the government accounting courses lies in developing a competent, adaptable and flexible professional. With that in mind, it is easy to realize that the regulations that must be obeyed by the accountant directly affect this training. These rules include IPSAS, which represent the best quality parameter as the basis for the preparation of public accounts.

The nomenclatures found indicate the number of different subjects that are considered important for the training of each public institution of higher education. They point out that institutions consider it important to offer disciplines on budget, regulations, equity, reports, and on the accrual basis.

\subsection{Amount of courses, semester and workload}

The 76 public institutions of higher education in Brazil offer the Accounting programme. They provide an average of 3 government accounting related courses per institution, averaging 61.87 hours per course. In the case of Mexico, of the 39 public institutions of higher education, 28 offer the programme (11 do not offer). The average number of couses per institution is 2 , lower than the Brazilian one.

In Mexico, 16 public institutions of higher education have at least one government accounting course, the analysis shows that $47 \%$ of the institutions have courses that refer to the public sector and spend an average of 100 hours per course. The Undergraduation programme varies from 4 to 5 years. The institutions with the largest number of courses are the National Autonomous University of Mexico, and Benemérita University of Guadalajara, with 6 courses; and Autonomous State of Mexico, Autónoma Benito Juárez de Oaxaca, San Luis Potosí, and Zacatecas, with 4 courses.

In Brazil, $100 \%$ of the sample institutions have at least one government accounting course, that is, all the 76 universities. The undergraduation programme also varies from 4 to 5 years. The average workload for government accounting courses is 125 hours. The institutions that stand out in the amount of offered courses are the University of Brasília, with 9 courses, the Federal University of Viscosa, the Federal University of Rio Grande do Norte and the State University of Rio Grande do Norte, with 7 government accounting courses. In Table 3 - Semester of government accounting courses shows the semester of the each courses. It was can see that most universities offer courses regarding government accounting in the 8th semester in Mexico and the 6th semester in Brazil. 
Table 3 - Semester of government accounting courses.

\begin{tabular}{ccc} 
Semester & Brazil & Mexico \\
\hline 1st & 1 & 0 \\
\hline 2nd & 0 & 0 \\
\hline 3rd & 7 & 0 \\
\hline 4th & 28 & 3 \\
\hline 5th & 37 & 1 \\
\hline 6th & 42 & 11 \\
\hline 7th & 19 & 19 \\
\hline 8th & 16 & 23 \\
\hline 9th & 2 & 6 \\
\hline 10th & 2 & 2 \\
\hline
\end{tabular}

Source: Research data.

In Table 3 It was can see that most universities offer courses regarding government accounting in the 8th semester in Mexico and the 6th semester in Brazil.It is worth emphasizing that the student can have his first contact on the introductory principles, administrative structure, government accounting and public finances in the intermediate semesters, as done in Brazil. In this way, you can dedicate more hours to specific Public Accounting issues, therefore, to IPSAS as well. This manner, the students can be better prepared on the latest issues in the area.It was emphasize that it do not consider it essential that these subjects be taught in the initial semesters. Since government accounting is based on different concepts from corporate accounting, there can be a confusion of concepts, ergo undermining the learning process.

\section{Discussion and Conclusion}

This work emphasizes that the Brazilian National Treasury initially neglected the influence of professionalism force from higher Education (normative isomorphism). Although academics were invited to participate from strategy Group, it was not enough to represent more than one thousand of public and private Accounting programmes in Brazil (e-mec, 2019) and some issues were not considered by both countries, such as:

(i) In both countries, the teaching and the National Treasury Handbook (first version in 2012) were dissociated: the information designed by professionals to professional does not reach students and the education were not supported based in the intention to introduce new procedures for students and new professionals;

(ii) professors and researchers did not account for support or trainings indicating how to change from budgetary culture to accrual basis, emphasizing the importance of both control systems. Au contraire, the situation in both Brazil and Mexico was different - professors and researches did have proper training. In addition, the use of technical terms extracted from the manual in classes directed to new students of this theme can act as a demotivation and undermine the educational process;

(iii) the Brazilian public universities represent a benchmark to other private universities that offer an Accounting programme, representing a mimetic isomorphism and portraying a role of legitimating the other particular Accounting programmes. Despite their relevance, the public institutions were not required or invited to participate in the group of discussion and training to introduce IPSAS. In Brazil for example, there are many differences between geographic regions, which were historically influenced by occupation, climate and other factors that could be facilitated through a representation of each university.

In point (ii) we focus on the professor and in point (iii) on the role that the university could develop by means of extracurricular activities and support in the strategies of the government in promoting the efficiencies of the public resources 
through the IPSAS adoption. In addition, students' engagement in the various public sector bodies conducting monitored activities could facilitate the inclusion of patrimonial practices, such as asset counting, measurement problems, and specific controls within the various realities of the public sector.

In the present research, it was compare the current situation of teaching of courses related to the Public Sector in Public Institutions of Higher Education, in Brazil and Mexico. The results show that the diversity found indicates the need to reform the offerings of courses related to the subject, taking into account the established deadlines, as well as the extensions given, and the importance of having competent professionals. It was also note the relevance due to the impact of the professionals' competence in the management of public resources and, therefore, in the improvements for the State and wellbeing of citizens.

In the 76 Brazilian and in the 39 Mexican public institutions of higher education, it was possible to observe the great variety in the courses offer. If institutional legitimacy consider education in Mexican and Brazilian IPSAS adoption strategies the diffusion of IPSAS accrual accounting information will account for a huge network of more than 1000 of people involved. All public institutions of higher education have at least one mandatory course in Brazil, while in Mexico only 25 are offered as mandatory. Considering this situation, it was highlight the need to establish a model with minimal disciplines. The current demand for greater transparency, which avoids fraud and public management - a recurrent problem in both countries coincides with the urgent reform of higher education curriculum regarding government accounting.

One of the limitations of this study consists of not analyzing the syllabus of the government accounting courses, in order to verify the topics and if the contemporary issues on the subject are approached.

The limitations of this study offers direction for future research. Thus, we suggest including in the research the study of the syllabus of each government accounting course. In addition, it is relevant to have researches and discussions on the establishment of a model government accounting syllabus, which could provide guidance in order to achieve a more homogeneous education. It is believe that another topic for future research includes the development of educational materials that conciliates public and private sector issues, thus generating interdisciplinarity (Miranda \& Miranda, 2006). At last, afurther line of research is a discussion of successful practices in other countries that can be followed as a government accounting teaching model.

\section{References}

Abdulkarim, M. E., Umlai, M. I., \& Al-Saudi, L. F. (2020). Exploring the role of innovation in the level of readiness to adopt IPSAS. Journal of Accounting \& Organizational Change.

Abreu, R. (2015). Accounting for citizenship: The role of accountant. Procedia Economics and Finance, 26, 933-941.

Ademola, A. O., Ben-Caleb, E., Madugba, J. U., Adegboyegun, A. E., \& Eluyela, F. D. (2020). International public sector accounting standards (IPSAS) adoption and implementation in Nigerian public sector. International Journal of Financial Research, 11(1), 434-446.

Araújo, J. C. O., da Silva, K. M. D. S., Lima, F. G. V., \& dos Santos Silva, A. (2018). Controladoria na gestão pública: um estudo na unidade de controle interno (UCI) do município de Castanhal sob a ótica da Lei de Responsabilidade Fiscal (LRF). Brazilian Journal of Development, 4(7), $3755-3772$.

Arquero, J. L., Fernández-Polvillo, C., Hassall, T., \& Joyce, J. (2015). Relationships between communication apprehension, ambiguity tolerance and learning styles in accounting students. Revista de Contabilidad. http://dx.doi.org/10.1016/j.rcsar.2015.10.002

Briggs, S. P., Copeland, S., \& Haynes, D. (2007). Accountants for the 21st century, where are you? A five-year study of accounting students' personality preferences. Critical Perspectives on Accounting, 18(5), 511-537.

Byrne, M., Flood, B., \& Willis, P. (2002). The relationship between learning approaches and learning outcomes: A study of irish accounting students. Accounting Education, 11(1), 27-42.

Cardoso, R. L., \& Riccio, E. L. (2010). Existem competências a serem priorizadas no desenvolvimento do contador? Um estudo sobre os contadores brasileiros. REGE Revista de Gestão, 17(3), 353-367.

Caruana, J. (2021). The proposed IPSAS on measurement for public sector financial reporting — recycling or reiteration? Public Money \& Management, 41(3), 184-191. 
Consejo Nacional de Armonización Contable (CONAC). (s.f.). Normatividad Vigente. México: CONAC. Recuperado el 12/03/2019 de: http://www.conac.gob.mx/es/CONAC/Normatividad_Vigente

Cordón, J. A. (2001). Manual de investigación bibliográfica y documental. Teoría y práctica. Pirámide. p. 46-60.

Crawford, L., Helliar, C., Monk, E., \& Veneziani, M. (2014). International accounting education standards board: Organisational legitimacy within the field of professional accountancy education. Accounting Forum, 38(1), 67-89.

Del Castillo, G. (2005). El impacto de la evaluación externa en dos instituciones de educación superior en México: la Universidad Autónoma MetropolitanaAzcapotzalco y la Universidad Iberoamericana. Perfiles latinoamericanos, 13(25), 115-148.

Dellaportas, S., \& Hassall, T. (2013). Experiential learning in accounting education: A prison visit. The British Accounting Review, 45(1), 24-36.

Dias, G. N., Silva, P. R. S., Pamplona, V. M. S., Araújo, J. C. O., Barbosa, E. da S., Lobato, F. da S., Souza Júnior, J. C. B., Silva Junior, W. L. P., Vogado, G. E. R., Barreto, W. D. L., Leal, A. P. I. P., Silva Junior, A. F., \& Pinto, G. P. (2021). A utilização do Formulários Google como ferramenta de avaliação no processo de ensino e aprendizagem em tempos de pandemia de Covid-19: Um estudo em uma escola de educação básica. Research, Society and Development, 10(4), e44910414180. https://doi.org/10.33448/rsd-v10i4.14180.

El Economista (EE). (2014). Positivos los 20 años de México en la OCDE. México: EE. Recuperado el 29/04/2017 de: http://eleconomista.com.mx/finanzaspublicas/2014/05/19/positivos-20-anos-mexico-ocde

Etzkowitz, H., Webster, A., Gebhardt, C., \& Terra, B. R. C. (2000). The future of the university and the University of the Future: Evolution of ivory tower to entrepreneurial paradigm. Research Policy, 29(2), 313-330.

Flores, V.D. (junio 1994). El ingreso de México a la OCDE. México: Comercio Exterior. http://revistas.bancomext.gob.mx/rce/magazines/360/22/RCE16.pdf

Gil, A. C.(2002). Como Elaborar Projetos de Pesquisa. (4a ed.) Atlas.

Gómez-Villegas, M., Brusca, I., \& Bergmann, A. (2020). IPSAS in Latin America: innovation, isomorphism or rhetoric? Public Money \& Management, 40(7), 489-498.

González, R.A., Valenzuela, O., y Beltrán, S.E. (2009). El Presente y Futuro de la Armonización Contable Gubernamental Mundial y Retos del Estado Mexicano. México: Revista Universidad Autónoma de Sinaloa. http://www.itson.mx/publicaciones/pacioli/Documents/no65/42.pdf

Guedes, L. C. M., Castro, W. A. de, \& Canedo, K. G. (2020). Contabilidade internacional: qualidade contábil após adoção das normas internacionais de contabilidade no Brasil. Research, Society and Development, 9(2), e121922079. https://doi.org/10.33448/rsd-v9i2.2079.

Howieson, B. (2003). Accounting practice in the new millennium: Is accounting education ready to meet the challenge? The British Accounting Review, 35(2), 69-103.

Ibarra, E. (2002). La 'nueva universidad' en México: transformaciones recientes y perspectivas. México: Revista Mexicana de Investigación Educativa. Vol. VII Núm. 14. Ene-abr. Pp. 75-105

Jorge de Jesús, M., \& Eirado, J. (2012). Relevance of accounting information to public sector accountability: A study of brazilian federal public universities. Tékhne, 10(2), 87-98. Retrieved from http://dx.doi.org/10.1016/j.tekhne.2012.10.001.

Lakatos, E. M., \& Marconi, M. de A. (1991). Fundamentos de metodologia científica. (3a ed.), Atlas.

Lobato, Lenaura de Vasconcelos Costa. (2018). A questão social no projeto do BRICS. Ciência \& Saúde Coletiva, $23,2133-2146$.

Milne, M. J., \& McConnell, P. J. (2001). Problem-based learning: A pedagogy for using case material in accounting education. Accounting Education, 10(1), 61-82.

Ministerio de Educación y Cultura (Brasil). (2016). Sistema e-MEC. http://emec.mec.gov.br/

Ministerio de Hacienda, Secretaría del Tesoro Nacional (Brasil). (2004). Ordenanza STN no 219, del 29 abril de 2004. Aprova a $1^{\text {a }}$ edição do Manual de Procedimentos da Receita Pública. Brasília, DF. Recuperado de http://www3.tesouro.gov.br/legislacao/download/contabilidade/Portaria219.pdf

Ministerio de Hacienda, Secretaría del Tesoro Nacional (Brasil). (2015). Ordenanza STN nº548, de 24 de septiembre de 2015 . Dispõe sobre prazos limite de adoção dos procedimentos contábeis patrimoniais aplicáveis aos entes da Federação, com vistas à consolidação das contas públicas da União, dos estados, do Distrito Federal e dos municípios. Brasília, DF, Brasil. http://www.cnm.org.br/portal/images/stories/Links/30092015_CPU_Portaria_STN_548-2015__PIPCP1.pdf

Mnif, Y., \& Gafsi, Y. (2020). A contingency theory perspective on the analysis of central government accounting disclosure under International Public Sector Accounting Standards (IPSAS). Meditari Accountancy Research.

Pina, V., Torres, L., \& Yetano, A. (2009). Accrual accounting in EU local governments: One method, several approaches. European Accounting Review, 18(4), 765-807.

Pineda, A. Z., Canseco, E. A., y Herrera, M. E. S. (2014). La armonización contable en México y su relación con la educación superior. XIX Congreso Internacional de Contaduría, Administración e Informática. ANFECA-ALAFEC

Rahman, I. K. A., Rahman, N. A. A., Azhar, Z., Omar, N., \& Said, J. (2015). Management accounting best practices award for improving corruption in public sector agencies. Procedia Economics and Finance, 31, 503-509. http://dx.doi.org.ez77.periodicos.capes.gov.br/10.1016/S2212-5671(15)01192-2 
Research, Society and Development, v. 10, n. 9, e19510918059, 2021

(CC BY 4.0) | ISSN 2525-3409 | DOI: http://dx.doi.org/10.33448/rsd-v10i9.18059

Ramírez-Alujas, Á. V. (2011). El rol del Administrador Público en Chile: ¿Vale la pena vivir para este oficio? Una reflexión abierta sobre los desafíos que enfrenta la formación profesional universitaria de cara al siglo XXI. Estado, Gobierno y Gestión Pública, (17), pp-35.

Rebele, J. E., \& Pierre, E. K. S. (2015). Stagnation in accounting education research. Journal of Accounting Education, 33(2), 128-137.

Secretaría de Economía (SE). (2017). Tratados y acuerdos firmados con México. http://www.gob.mx/se/acciones-y-programas/comercio-exterior-paises-contratados-y-acuerdos-firmados-con-mexico

Simons, K., Higgins, M., \& Lowe, D. (1995). A profile of communication apprehension in accounting majors: Implications for teaching and curriculum revision. Journal of Accounting Education, 13(2), 159-176.

Soguel, N., \& Luta, N. (2021). On the road towards IPSAS with a maturity model: a Swiss case study. International Journal of Public Sector Management.

Sour, L. (2011). El sistema de contabilidad gubernamental que mejorará la transparencia y la rendición de cuentas en México. Revista "Transparencia y Privacidad", Núm. 1, primer semestre. Instituto Federal de Acceso a la Información y Protección de Datos. Recuperado el 01/04/2017 de: http://www.transparenciayprivacidad.org.mx/numero_1/articulos/esp/Art_2-Esp.pdf

Souza, F. G. (2016). The adoption of international public accounting standards in local brazilian governments. Paper presented at the XIX SemAd Seminários em Administração USP. http://login.semead.com.br/19semead/arquivos/806.pdf

Stanley, T., \& Marsden, S. (2013). Accountancy capstone: Enhancing integration and professional identity. Journal of Accounting Education, 31(4), 363-382.

Subsecretaría de Egresos (SE). (s.f.). Manual de Contabilidad Gubernamental para el Sector Paraestatal Federal. México: Secretaría de Hacienda y Crédito Público. Subsecretaría de Egresos. Unidad de Contabilidad Gubernamental. http://www.hacienda.gob.mx/LASHCP/MarcoJuridico/Contabilid adGubernamental/SCG_2013/manual\%20_SPF/doc/capituloi/mp1b01.pdf

Tormo-Carbó, G., Seguí-Mas, E., \& Oltra, V. (2016). Accounting Ethics in Unfriendly Environments: The Educational Challenge. Journal of Business Ethics, $135(1), 161-175.10 .1007 / \mathrm{s} 10551-014-2455-6$

Vásquez Quevedo, N. y Patiño Jacinto, R. A. (2015). O subsistema de formação contábil na Colômbia e no México. Revista Facultad de Ciencias Económicas 88.

Wilson, E. (2013). An historical perspective on governmental accounting education. Journal of Accounting Education, 31(3), $244-251$. 